\title{
Bioaccumulation of selected heavy metals in various organs of Sher Mahi (Clupisoma naziri) collected from local market of Peshawar
}

\author{
Sahibzada Muhammad Jawad ${ }^{1,2}$, Muhammad Zahid ${ }^{1}$, Mudassir \\ Shah $^{1 *}$, Muhammad Zeeshan Ashfaq ${ }^{2}$, Arshad Hayat ${ }^{3}$, Mohammad \\ Sayyar Khan ${ }^{4}$ and Syed Salman ${ }^{3}$ \\ 1. Department of Zoology Islamia College University Peshawar, KPK-Pakistan \\ 2. Department of Chemical and Life Sciences, Qurtuba University of Science and Information Technology, \\ Peshawar, KPK-Pakistan \\ 3. Deparment of Chemistry, Islamia College University, Peshawar, KPK-Pakistan \\ 4. Genomics and Bioinformatics Division, Institute of Biotechnology and Genetic Engineering (IBGE), The \\ University of Agriculture Peshawar, KPK-Pakistan \\ *Corresponding author's email: mshahsafi75@gmail.com \\ Citation
}

Sahibzada Muhammad Jawad, Muhammad Zahid, Mudassir Shah, Muhammad Zeeshan Ashfaq, Arshad Hayat, Mohammad Sayyar Khan and Syed Salman. Bioaccumulation of selected heavy metals in various organs of Sher Mahi (Clupisoma naziri) collected from local market of Peshawar. Pure and Applied Biology. Vol. 9, Issue 4, pp2225-2232. http://dx.doi.org/10.19045/bspab.2020.90238

\begin{tabular}{llll}
\hline \hline Received: 17/02/2020 & Revised: 10/06/2020 & Accepted: 14/06/2020 & Online First: 07/07/2020 \\
\hline
\end{tabular}

\section{Abstract}

The current study presents evaluation of heavy metals such as Zinc, Copper, Ni and Chromium level in various organs of freshwater angel species Clupisoma naziri. The level of each meal was recoded in gills, skin, liver, digestive system and muscles by PerkinElmer (2380) spectrometer protocol. The liver exhibited the most noteworthy metallic burden followed by gills, muscles, skin and digestive tract. The order of overall metallic burden in all parts collectively was $\mathrm{Ni}>\mathrm{Cr}>\mathrm{Zn}>\mathrm{Pb}>\mathrm{Cu}$ with the normal values of $2.93,2.27,1.66,0.93$ and $0.0956 \mathrm{ppm}$ respectively. Compared to maximum periwinkle limits as that of given by Food and Agriculture Organization (FAO), Zinc, Nickel and Copper were found within the permissible range whereas Chromium $(2.27 \mathrm{ppm})$ and Lead $(0.926 \mathrm{ppm})$ were found higher than reasonable limits i.e. $1 \mathrm{ppm}$ and $0.5 \mathrm{ppm}$ respectively.

Keywords: Atomic Absorption; Bioaccumulation; Clupisoma naziri; Heavy metals;

Spectrophotometer

\section{Introduction}

Heavy metals are characteristic components of earth's body, Water has distinctive kind of properties making it capable of breaking down, adsorb, acclimatize or suspend various external properties. These metals enter to water bodies through common starting such as deteriorated minerals interior residue, shifting of metal stores and volcanism expelled things or industrial and buyer squander or anthropogenic root checking solid misuse exchange, mechanical or chemical effluents, harbor channel burrowing or without a hesitation from acidic rain. Heavy metals may also release from soil into ground water, lakes, conduits and streams. These metals are preeminent common, normally harmful if exceeded the maximum permissible range and cause veritable peril such as long determination, biomagnification and bioaccumulation 
inside food chain [1, 2]. These metals exist in various chemical forms such as oxides, metal carbonates, sulfides, and particles in precious stone cross sections of minerals that influence the capacity of their mobility and bioavailability [3-5]. Being not metabolized, heavy metals pose thread to the body which eventually gathers in delicate tissues . In case it comes to the harmful level, these irresistible metals possibly exasperate the biological environment [6-8]. The rate of this impact of

articulation significantly depends on the level of industrialization and the utilization of

mechanical agrarian exercises and as well as on unrestrained urbanization along the coastal zones.

Many metropolitan cities are now facing the problem of environmental pollution among which heavy metals pollution is alarming. The entering of toxic metals into the ecosystem may lead to bioaccumulation, biotransformation, biomagnifications and geo-accumulation. Depending on the quantity and nature of the metal ingested, heavy metals can cause serious health issues with varied symptoms [9]. However excess exposure to these metals can be toxic.

Fish is among important foods globally, offering a rich source of vitamins, minerals, digestible protein, and polyunsaturated fatty acids, [10] supporting healthy life [11]. However, the dense metals content accumulated in fish organs cause a few serious disorders such as cardiovascular diseases, renal failure and liver damage [12-14]. Digestive track, gills and body surface are the common side of entrance of heavy metals[15, 16] while the concentration of accumulated heavy metals may also depends on size and age of species [17], their life cycle and life history, ecological needs, feeding habits [18], capturing season, and physio-chemical parameters of water [19]. The most common heavy metals are aluminum, cadmium, arsenic, lead, mercury, calcium, zinc, iron, magnesium, cobalt and cadmium. Specific amount of some of these metals are necessary for certain biological functions such as calcium, magnesium, potassium and Iron in a reasonable amount while others are potentially dangerous for biological systems [20-22].

The insight study of toxic metals, their accumulation in the soil and particularly their impact on soil and water or plant system seems to be an important issue which must be addressed accordingly [23]. The focus of current study is to evaluate heavy metals profile of Clupisoma naziri. The study is important as the specie selected for evaluation is among most consumed specie. Thus, it is necessary to have insight into heavy metals profile of different parts of Clupisoma naziri.

\section{Materials and methods}

In this work, the bioaccumulations of several heavy metals were identified in numerous organs of Clupisoma naziri (Local name: shermahi) which is among widely consumed species of fish. The main source of $C$. naziri for local market is River Kabul. Nuclear Absorption Atomic Retention Spectrophotometer (PERKINELMER (2380) was used. Six distinctive species of $C$. naziri were collected from nearby markets of Peshawar, Khyber Pakhtunkhwa Pakistan and were immediately transferred to icebox for transportation to the research facility of Zoology division Islamia College Peshawar for further examination. Weighted parcel of gills, skin, muscles, liver and digestive tract were cut utilizing stainless steel sterile edges and were kept at solidifying temperature in sterilized polythene bags. The instrumental investigations were carried out in University of Peshawar, KPK

\section{Bioaccumulation of heavy metals in organs of fish} Digestion of samples

After morpho-metric measurements, the samples of fish were subjected to acid digestion, for which the reported protocol 
[24] was followed with some minor changes according to the illustrations of Yousafzai and Shakoori [25]. Briefly, washing of fish samples were done with distilled water. Using blotting paper, the analyzed parts i.e. gills, skin, muscles, liver and intestine were carefully blotted and a measured amount of every sample was transferred to separate volumetric flask of $100 \mathrm{~mL}$, and to each flask $5 \mathrm{~mL}$ nitric acid (55\%) and $2 \mathrm{~mL}$ perchloric acid (70\%) were added followed by keeping it air tight for whole night. Second dose of $5 \mathrm{~mL}$ nitric acid $(55 \%)$ and $3 \mathrm{~mL}(70 \%)$ perchloric acid were added to each flask after 25 hours. To get a transparent solution, flasks were kept for 20 minutes on hot plate of 200 to $250{ }^{\circ} \mathrm{C}$ for digestion. The dense white fumes from the flasks after brown fumes indicates the completion of the process of digestion. After digestion, samples diluted to $10 \mathrm{~mL}$ with nano pure water after being cooled. All the samples were properly filtered and transferred to sterile vials.

\section{Determination of metals concentration}

For the analysis of heavy metal through Atomic Absorption Spectrophotometer, Air acetylene flame was used while its distinctive lamp was set in flame Atomic Absorption Spectrophotometer. Initially, standard curve of each metal was obtained using a characteristic metal standard solution, followed by analysis of samples that were to be investigated for evaluation of heavy metals concentration.

Atomic Absorption Spectrophotometer (Perkin Elmer 2380) was operated to analyze the level of metals of interest: $\mathrm{Cu}$ (Copper), $\mathrm{Zn}$ (Zinc), Ni (Nickel), $\mathrm{Cr}$ (Chromium) and $\mathrm{Pb}$ (Lead) in the skin, muscles, liver intestine and gills samples of each fish collected. Each sample was tested and examined in triplet; organized space ranges of analytical standards for all metals were made ready using E. Merck Stock solution. The acquired ODs were calibrated against the standard curves which were prepared to check out the quantity of all heavy metals in samples under study. Level of each heavy metal was represented in ppm (Parts Per Million).

\section{Statistical methods}

The data of current study was processed through analysis and results were shown as average/mean \pm S.E.

\section{Results and discussion}

In each organ. Concentration of each metal was found to be different. The tables and graphs below show the results of all metals concentration in ppm that was assessed in different organs.

By taking the average, the study reveals that the following order of concentration of these heavy metals were $\mathrm{Ni}>\mathrm{Cr}>\mathrm{Zn}>\mathrm{Pb}>$ $\mathrm{Cu}$ with exception in intestine and muscles where $\mathrm{Cr}$ was in highest concentrating followed by $\mathrm{Ni}, \mathrm{Zn}, \mathrm{Pb}$ and $\mathrm{Cu}$ (Fig. 1).

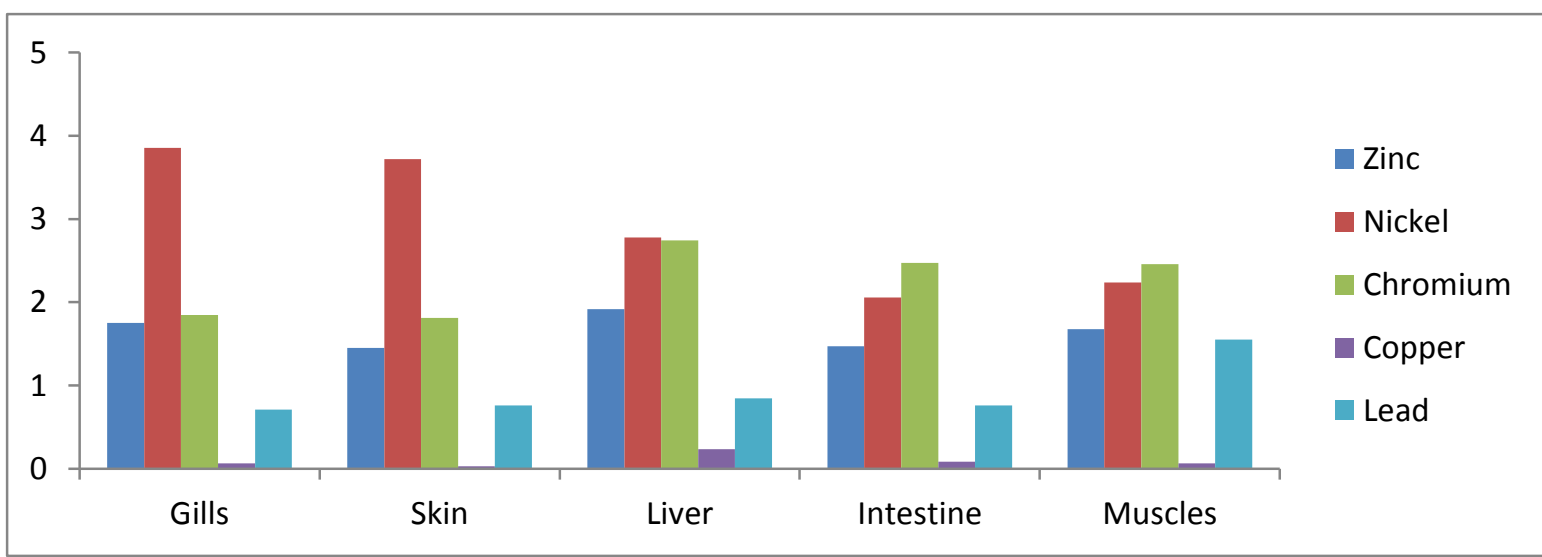

Figure 1. Showing Bioaccumulation of heavy metals in various organs of $C$. naziri collected from various areas. $X$-axis shows concentration $( \pm 0.001$ to \pm 0.4$)$ in $\mathbf{p p m}$ while Y-axis shows different organs 
Combined burden of all the metals is highest in the Liver that is $8.518 \mathrm{ppm}$ and burden in the Intestine is $6.85 \mathrm{ppm}$. The following order of bioaccumulation was observed in organs:

Gills $>$ Skin $>$ Liver $>$ Muscles $>$ Intestine. In order to maintain normal body functions, living creatures including fish, need heavy metals in specific amounts depending upon the nature of each metal. Excessive quantity of certain metals can be harmful for normal body functions, while some metals like mercury, lead and cadmium are not mandatory for normal cellular activities. Therefore, long lasting exposure to these metals may cause abnormalities [26]. Metallic elements can't be degraded by living organisms naturally and they accumulate through biosorption and metabolic process in aquatic organisms [27].

It has been reported that gills accumulate more heavy metals than digestive tract if they are taken up from water. Besides this, Digestive tract accumulates more heavy metals than gills if they are absorbed from various food materials [15]. Summarizing the above-mentioned fact, it can be said that if the metallic levels are higher in water, the food contribution to overall body weight will be inconsequential. This is because of higher concentration and transport efficiency across gills.

In this work, concentration of $\mathrm{Zn}$ was found to be less, compared to literature reported for gills of Chamma punctatus. [28], testis of L. niloticus and O. niloticus [29] $C$. punctatus respectively. [30]. Its concentration was higher in liver followed by gills, skin, muscles and intestine. Literature suggest that food as well as surrounding water may be largest source of $\mathrm{Zn}$ accumulation as $\mathrm{Zn}$ is imported constituent of certain foods [31, 32]. Higher mount of $\mathrm{Zn}$ can be toxic causing growth delaying, impermanency, and reproductive abnormality to fish. [33].

Generally higher amount of Nickel i.e above permissible level was noticed in the gills followed by liver, skin, muscles and intestine. $0.7 \mu \mathrm{g} / \mathrm{g}$ of Nickel's level is considered hypothetically fatal to fish and water dependent birds that devour them [34].

In the study of fish muscles from the Mediterranean coastal water, the average mass of Cr was $2.1 \mu \mathrm{g} / \mathrm{g}$. Even lower values were also reported from the Aqaba,s Gulf for the muscle of Parupeneus barberinus $(0.4 \mu \mathrm{g} / \mathrm{g}$.$) and Scarus variegatus is$ $0.6 \mu \mathrm{g} / \mathrm{g}$. [35]. However, in the present work, greater mass was seen in liver of the fish followed by intestine. Compared to literature, the site for maximum piles of $\mathrm{Cr}$ in W. attu and L. dyocheilus were gills [25]. Simililarly, this study revealed that Copper is present in high amount in liver followed by intestine, gills, muscles and skin but overall, the concentration of $\mathrm{Cu}$ was found to be less as compared to other heavy metals. Lead is very harmful for aquatic life especially for fish, as it accumulates on higher quantity in fish organs [36]. Our study revealed the presence of higher concentration of Lead in muscles followed by liver, skin and intestine while least in gills. Overall, the lead concentration was found to be above FAO limit [31].

Comparing the present data with the Maximum Allowable Limits (MPL) of international standards provided by Food and Agriculture Organization (FAO), it can be observed that the levels of Zinc, Nickel and Copper were found below the MPL with values of $1.65 \mathrm{ppm}, 6.93 \mathrm{ppm}$ and $0.096 \mathrm{ppm}$ respectively. On the other hand, Chromium (2.27 ppm) and Lead (0.926 ppm) are higher than permissible value 1 ppm and $0.5 \mathrm{ppm}$ respectively. The current observed metal value of Ni (2.9) (Fig. 2) is slightly higher than reported values [37], in a closely related species Clupisoma pseudeutropius in which the $\mathrm{Ni}$ was 2.1 ppm.

The existences of high mass of these heavy metals could be the result of human being activities not by natural enrichment from study of geological weathering [38]. Tanneries, textile, brewery pottery, metal fining, electroplating, mining and printing 
industries, pottery, electrical petroleum industries, pharmaceutical and graphic industries are some of the sources from where untreated waste materials enter water bodies [39]. Table 1 shows average concentration of each metal in comparison with FAO standards.

Comparing our results with literature, Ali et al. [40] determined reasonable amount of $\mathrm{Cr}, \mathrm{Ni}, \mathrm{Cd}$ and $\mathrm{Pb}$ in Skin, Gills, Liver and Kidney of $C$. naziri as well as in water maples collected from River Shah Alam which is originated from River Kabul while Ali and Khan [41] revealed the presence of $\mathrm{Cd}, \mathrm{Pb}$ and $\mathrm{Hg}$ heavy metals in 4 different species including $C$. naziri collected from River Kabul.

According to a study conducted by Ahmad et al. [42], the ultimate cause of heavy metals in both water and in fishes is anthropogenic activities among which the leading could be improper use of chemical fertilizers as well as disposal of waste materials. It has been reported that the major source of industrial waste that contributes to water pollution is marble industries causing physical and chemical alterations to the water bodies and the situation may get worse in future $[43,44]$. Our group conducted research on different parameters of water samples collected form River Kabul and the results suggest that the certain parameters were not according to the standard conditions and leading cause may the presence of different types of industries, marble industries being on top (Manuscript under review).

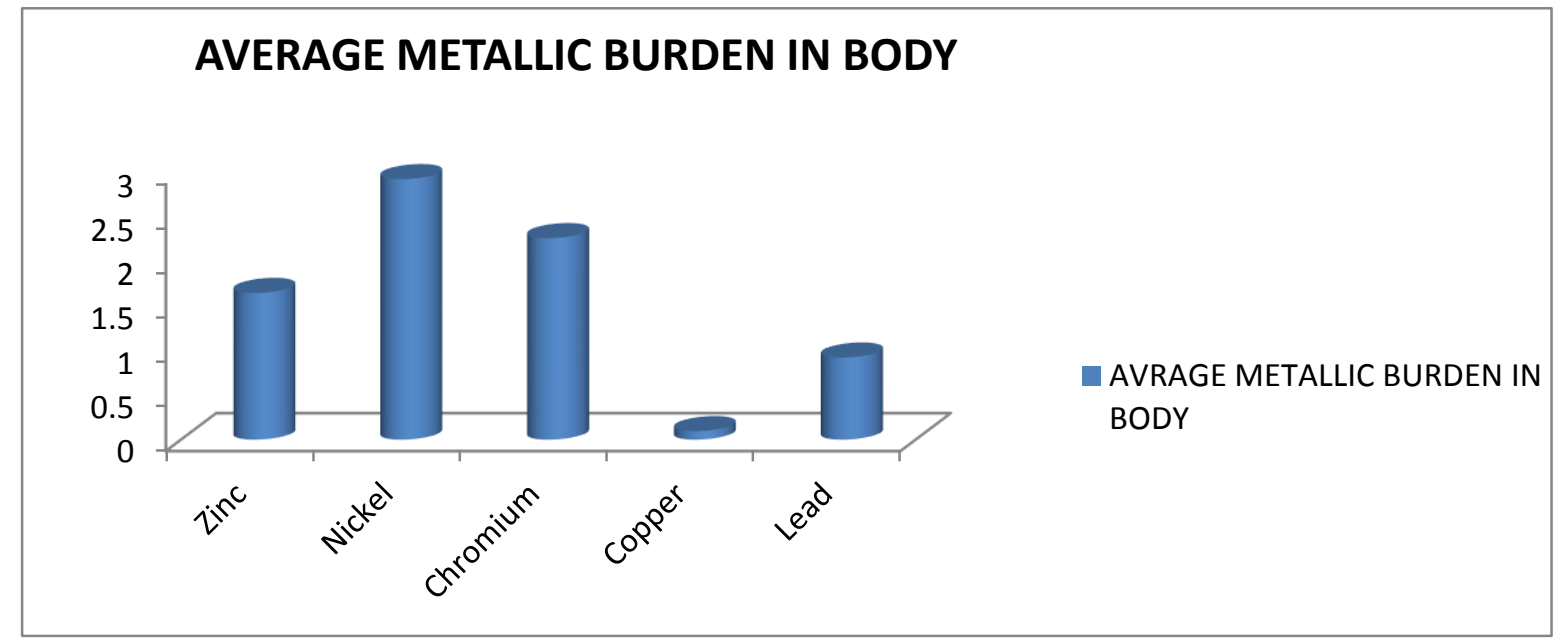

Figure 2. Average metallic burden in the various body organs of $C$. naziri. $\mathrm{X}$-axis shows concentration in ppm while y-axis shows different heavy metals

Table 1. Comparison between FAO standards and average heavy metal concentration in fish C. naziri

\begin{tabular}{|c|c|c|c|}
\hline S. No. & Metal & Observed Value & FAO Limits \\
\hline $\mathbf{1}$ & $\mathrm{Zn}$ & $1.65 \pm 0.09$ & 30 \\
\hline $\mathbf{2}$ & $\mathrm{Ni}$ & $2.93 \pm 0.04$ & 5.5 \\
\hline $\mathbf{3}$ & $\mathrm{Cr}$ & $2.27 \pm 0.03$ & 1 \\
\hline $\mathbf{4}$ & $\mathrm{Cu}$ & $0.096 \pm 0.001$ & 30 \\
\hline $\mathbf{5}$ & $\mathrm{Pb}$ & $0.926 \pm 0.001$ & 0.5 \\
\hline
\end{tabular}

\section{Conclusion}

Over study revealed that overall burden of heavy metals is highest in the liver and lowest in the intestine followed by muscles and skin. The highest value of accumulation was shown by $\mathrm{Ni}$ followed by $\mathrm{Cr}, \mathrm{Zn}, \mathrm{Pb}$ and $\mathrm{Cu}$. Comparison of these metals with standards provided by FAO, indicates that $\mathrm{Zn}, \mathrm{Ni}$ and $\mathrm{Cu}$ levels are in normal range while $\mathrm{Cr}$ and $\mathrm{Pb}$ are slightly 
higher than the permissible limits. This study is of particular importance as the selected specie is among the most consumed fish in the local region.

\section{Authors' contributions}

Conceived and designed the experiments: M Zahid, Performed the experiments: SM Jawad \& MZ Ashfaq, Analyzed the data: A Hayat \& S Salman, Contributed materials/ analysis/ tools: MS Khan, Wrote the paper: M Shah.

\section{References}

1. Papagiannis I, Kagalou I, Leonardos J, Petridis D \& Kalfakakou (2004). Copper and zinc in four freshwater fish species from Lake Pamvotis (Greece). Environ Inter 30(3): 357-362.

2. Marcovecchio JE, Botté SE \& Freije RH (2007). Heavy metals, major metals, trace elements. Handbook of Water Anal 2: 275-311.

3. Lee SV \& Cundy AB (2001). Heavy metal contamination and mixing processes in sediments from the Humber Estuary, Eastern England. Estuarine, Coastal and Shelf Sci 53(5): 619-636.

4. Lopez-Sanchez JF, Rubio R, Samitier C \& Rauret G (1996). Trace metal partitioning in marine sediments and sludges deposited off the coast of Barcelona (Spain). Water Res 30(1): 153-159.

5. Morillo J, Usero J \& Gracia I (2004). Heavy metal distribution in marine sediments from the southwest coast of Spain. Chemosph 55(3): 431-442.

6. Agusa T, Kunito T, Sudaryanto A, Monirith I, Kan-Atireklap S, Iwata H \& Tana TS (2007). Exposure assessment for trace elements from consumption of marine fish in Southeast Asia. Environ Pollution 145(3): 766-777.

7. Agusa T, Kunito T, Yasunaga G, Iwata H, Subramanian A, Ismail A \& Tanabe $S$ (2005). Concentrations of trace elements in marine fish and its risk assessment in Malaysia. Marine Pollution Bull 51(8-12): 896-911.
8. Hajeb $\mathrm{P}$, Jinap $\mathrm{S}$, Ismail A, Fatimah AB, Jamilah, B \& Rahim MA (2009). Assessment of mercury level in commonly consumed marine fishes in Malaysia. Food Control 20(1): 79-84.

9. Moore JW \& Ramamoorthy S (2012). Heavy metals in natural waters: Applied monitoring and impact assessment. Springer Science \& Business Media.

10. Carvalho M, Santiago $S \&$ Nunes $M L$ (2005). Assessment of the essential element and heavy metal content of edible fish muscle. Anal Bioanal Chem 382(2): 426-432.

11. Ikem A \& Egiebor NO (2005). Assessment of trace elements in canned fishes (mackerel, tuna, salmon, sardines and herrings) marketed in Georgia and Alabama (United States of America). J of Food Composition and Analy 18(8): 771-787.

12. Castro-González MI \& MéndezArmenta M (2008). Heavy metals: Implications associated to fish consumption. Environ Toxicol and Pharmacol 26(3): 263-271.

13. Al-Busaidi M, Yesudhason P, AlMughairi S, Al-Rahbi WAK, AlHarthy KS, Al-Mazrooei NA \& AlHabsi SH (2011). Toxic metals in commercial marine fish in Oman with reference to national and international standards. Chemosph 85(1): 67-73.

14. Rahman MS, Molla AH, Saha N \& Rahman A (2012). Study on heavy metals levels and its risk assessment in some edible fishes from Bangshi River, Savar, Dhaka, Bangladesh. Food Chem 134(4): 1847-1854.

15. Dallinger R, Prosi F, Segner H \& Back $\mathrm{H}$ (1987). Contaminated food and uptake of heavy metals by fish: A review and a proposal for further research. Oecologia 73(1): 91-98.

16. Pourang N (1995). Heavy metal bioaccumulation in different tissues of two fish species with regards to their feeding habits and trophic levels. 
Environ Monitoring and Asses 35(3): 207-219.

17. Newman MC \& Doubet DK (1989). Size-dependence of mercury (II) accumulation kinetics in the mosquitofish, Gambusia affinis (Baird and Girard). Archives of Environ Contamination and Toxicol 18(6): 819-825.

18. Canpolat Ö \& Çalta M (2003). Heavy metals in some tissues and organs of Capoeta capoeta umbla(Heckel, 1843) fish species in relation to body size, age, sex and seasons. Fresenius Environ Bull 12(9): 961-966.

19. Zheng NA, Wang Q, Liang Z \& Zheng D (2008). Characterization of heavy metal concentrations in the sediments of three freshwater rivers in Huludao City, Northeast China. Environ Poll 154(1): 135-142.

20. Bakare-Odunola MT (2005). Determination of some metallic impurities present in soft drinks marketed in Nigeria. The Nig J Pharm 4(1): 51-54.

21. Hammer MJ (2004). Water Quality. In: Water and Wastewater Technology. 5th Edn. New Jersey: Prentice-Hall 139-159.

22. Canli M \& Atli G (2003). The relationships between heavy metal $(\mathrm{Cd}, \mathrm{Cr}, \mathrm{Cu}, \mathrm{Fe}, \mathrm{Pb}, \mathrm{Zn})$ levels and the size of six Mediterranean fish species. Environ Poll 121(1): 129-136.

23. Rajesh KS, Madhoolika A \& Marshall FM (2004). Effect of Wastewater Irrigation on Heavy Metal Accumulation in Soil and Plants, Paper Presented at a National Seminar, Bangalore University, Bangalore, Abstract 7- 8.

24. Balcerzak M (2002). Sample digestion methods for the determination of traces of precious metals by spectrometric techniques. Analytical Sci 18(7): 737750 .

25. Yousafzai AM \& Shakoori AR (2008). Heavy metal accumulation in the gills of an endangered South Asian freshwater fish as an indicator of aquatic pollution. Pak J of Zool 40(6): 423-430.

26. Azaman F, Juahir H, Yunus K, Azid A, Kamarudin MKA, Toriman ME, Saudi ASM (2015). Heavy metal in fish: Analysis and human health-a review. $J$ Teknol 77(1).

27. Hodson PV (1988). The effect of metal metabolism on uptake, disposition and toxicity in fish. Aquatic Toxicol 11(12): 3-18.

28. Shukla V, Dhankhar M, Prakash J \& Sastry KV (2007). Bioaccumulation of $\mathrm{Zn}, \mathrm{Cu}$ and $\mathrm{Cd}$ in Channa punctatus. $J$ of Environ Biol 28(2): 395.

29. Charbonneau CS \& Nash T (1993). Contaminants Program, Mingo National Wildlife Refuge (Region 3), Contaminants Survey Results. US Fish and Wildlife Service, 608.

30. Murugan SS, Karuppasamy R, Poongodi K \& Puvaneswari S (2008). Bioaccumulation pattern of zinc in freshwater fish Channa punctatus (Bloch.) after chronic exposure. Turk $J$ Fish Aquat Sci 8(1): 55-59.

31. Nauen CE (1983). Compilation of legal limits for hazardous substances in fish and fishery products. FAO Fisheries Circular (FAO). No. 764.

32. Aly MY (n.d.). Comparison of heavy metals levels in muscles, liver and gills of three fish species collected from agricultural drainage water AT ElAbbassa fish farm, Sharkia, Egypt.

33. Singh A \& Agrawal M (2010). Effects of municipal waste water irrigation on availability of heavy metals and morpho-physiological characteristics of Beta vulgaris L. 10.

34. Lemly AD (1993). Guidelines for evaluating selenium data from aquatic monitoring and assessment studies. Environ Monitoring and Asses 28(1): 83-100.

35. Wahbeh MI, \& Mahasneh DM. (1987). Concentrations of metals in the tissues of six species of fish from Aqaba, Jordan. Dirasat Sci 14(12): 119-129. 
36. Rompala JM, Rutosky FW \& Putnam DJ (1984). Concentrations of environmental contaminants from selected waters in Pennsylvania. US Fish and Wildlife Service Report. State College, Pennsylvania, 102

37. Amin MN, Begum A \& Mondal MK (2011). Trace element concentrations present in five species of freshwater fish of Bangladesh. Bangla J of Sci and Indus Res 46(1): 27-32

38. Davies C A, Tomlinson K \& Stephenson T (1991). Heavy metals in River Tees estuary sediments. Environ Technol 12(11): 961-972

39. Azzaoui S, Hanbali ME \& Leblanc M (2002). Note technique-Cuivre, plomb, fer et manganèse dans le bassin versant du Sebou; Sources d'apport et impact sur la qualité des eaux de surfaceTechnical Note-Copper, Lead, Iron and Manganese in the Sebou Drainage Basin; Sources and Impact on Surface Water Quality. Water Quality Res J 37(4): 773-784

40. Hazrat A, Ezzat K \& Muhammad JN (2020) Bioaccumulation of Some Potentially Toxic Heavy Metals in
Freshwater Fish of River Shah Alam, Khyber Pakhtunkhwa, Pakistan. Pak J Zool 52(2): 603-608

41. Ali H \& Khan E (2018) Assessment of potentially toxic heavy metals and health risk in water, sediments, and different fish species of River Kabul, Pakistan. Hum Ecol Risk Assess 24: 2101-2118.

42. Kabir A, Azizullah A, Shama S \& Muhammad NKK

Determination of heavy metal contents in water, sediments, and fish tissues of Shizothorax plagiostomus in river Panjkora at Lower Dir, Khyber Pakhtunkhwa, Pakistan, Environ Monit Assess 186: 7357-7366

43. Shahi M, Azizullah A, Abdul LK \& Muhammad NKK (2015) Impact of marble industry effluents on water and sediment quality of Barandu River in Buner District, Pakistan Environ Monit Assess 187:8

44. Shahi M, Abdul K, Azizullah A \& Muhammad NKK (2016) Decreased fish diversity found near marble industry effluents in River Barandu, Pakistan. Ecotoxicol 25: 132-140. 